\title{
Hiusrusettien politiikkaa lasten arkielämässä
}

Aikuisten järjestämiin poliittisiin toimintoihin, kuten kommunististen puolueiden pioneeriliikkeisiin tai kesällä järjestettyihin työleireihin, osallistuminen oli keskeinen osa lasten elämää sosialistisissa yhteiskunnissa. Tässä artikkelissa tarkastelemme henkilökohtaisten muistitarinoidemme kautta lasten jokapäiväisen poliittisen elämän neuvottelutilanteita esikouluissa ja alakouluissa Unkarissa ja kolmessa entisessä neuvostotasavallassa keskittymällä erityisesti koulupukuihin ja tyttöjen hiuksiin kiinnitettyihin rusetteihin. Näytämme miten banaalit esineet - erityisesti rusetit - sekä niihin liittyvät diskurssit ja käytännöt, tarjosivat poliittisen subjektiuden kehitysmahdollisuuksia erilaisissa geopoliittisissa ja henkilökohtaisissa ympäristöissä. Muistitarinoidemme kautta problematisoimme vallitsevan käsityksen sosialistisesta koulujärjestelmästä yksiselitteisesti tukahduttavana ja monipuolistamme ymmärrystämme politiikasta tuomalla esiin lasten politiikan.

Zsuzsa Millei, Nelli Piattoeva, Iveta Silova \& Elena Aydarova

Aikuisten järjestämiin poliittisiin toimintoihin, kuten kommunististen puolueiden pioneeriliikkeisiin tai kesällä järjestettyihin työleireihin, osallistuminen oli keskeinen osa lasten elämää sosialistisissa yhteiskunnissa. Tutkimuksessa lasten ja politiikan suhdetta on kuitenkin tarkasteltu lähinnä poliittisen sosialisaation viitekehyksessä (Connell 1987). Rautaesiripun molemmin puolin tutkijat näkivät lapset ikään kuin säiliöinä, joihin syötetään poliittisia normeja ja arvoja sekä poliittisessa järjestelmässä hyväksyttäviä ja haluttuja käyttäytymismalleja (Kallio \& Häkli 2011; Mead \& Silova 2013; Millei 2011; Philo \& Smith 2003; Skelton 2010). Ylhäältä alaspäin suuntautuva poliittinen sosialisaatio asemoi lapset passiivisiksi 
objekteiksi ja jätti huomiotta lasten subjektiuden, toimijuuden ja arkielämän poliittisuuden (Connell 1987; Kallio 2014).

Vasta uuden lapsuuden sosiologian nousun aikana 1990-luvulla lasten roolia yhteiskunnassa arvioitiin uudelleen, jolloin tunnistettiin myös lasten aktiivinen osallisuus elämässä ja yhteiskunnassa. Ymmärrys lasten ja politiikan suhteesta kehystyi tutkimuksessa uudelleen: alettiin tutkia, miten lapset ovat osallisina muokkaamassa instituutioita, heitä itseään ja muita, sekä hyväksyttiin, että lapsia kasvatetaan toimimaan lukemattomiin yhteiskunnallisiin instituutioihin ja rooleihin (esim. Kallio \& Häkli 2011; Philo \& Smith 2003; Skelton 2013). Huomion siirryttyä pois yksinomaan aikuisten luomista politiikan kentistä tutkijat ovat alkaneet kiinnostua myös siitä, miten politiikka lävistää lasten arkielämän antaen heille omat poliittiset asemansa ja roolinsa (Kallio \& Häkli 2011, 21). Korostaen politiikan yhteiskuntarakenteita ylläpitävää luonnetta ja lasten perinteistä asemoimista alaikäisiksi, ei-täysivaltaisiksi kansalaisiksi, Kallio ja Häkli $(2011,27)$ ovat ehdottaneet sen tutkimista, miten lapset toimivat poliittisesti, kun he vähä vähältä omaksuvat paikkansa yhteisönsä ja yhteiskuntansa täysivaltaisina jäseninä - ja harjoittelevat poliittisia subjektiuden ja toimijuuden tapoja. Tästä näkökulmasta lasten poliittiset maailmat lomittuvat aikuisten poliittisiin maailmoihin "tavallisessa elämässä" (Taylor 1989), jossa lapset suorittavat banaaleja mutta mahdollisesti poliittisesti latautuvia käytäntöjä suhteessa instituutioihin, mediaan sekä vertaiskulttuuriin (Kallio \& Häkli 2011, 104).

Käyttäen tätä näkökulmaa lähtökohtana olemme kiinnostuneita siitä tilasta lasten elämässä, joka jää "virallisen" politiikan piirin ulkopuolelle. Philo ja Smith (2003) erottavat toisistaan "P"olitiikan ja "p"olitiikan (tai makro- ja mikropolitiikan). "P"olitiikka viittaa aikuisten luomiin poliittisiin kenttiin, joissa lapset ovat osallisina, kun taas "p"olitiikka on lasten luoma poliittinen kenttä. On myös huomioitava Philon ja Smithin (2003) tekemä erottelu henkilökohtaisen politiikan ja mikropolitiikan välillä: siinä missä henkilökohtaisen politiikan pyrkimyksenä on saada valtaa omien välittömien olemassaolon ehtojen yli, mikropolitiikka ei ole individualistista, vaan se perustuu tapoihin, joilla ihmisryhmät toimivat yhdessä. Lasten politiikka resonoi heidän omien näkemyksiensä, tarinoidensa, toiveidensa ja pelkojensa kanssa (Philo \& Smith 2003, 109). Tässä mielessä kouluruokavaihtoehdot, yritys ottaa kouluissa käyttöön pakolliset koulupuvut tai jopa se, miten koulun leikkikentän säännöt on järjestetty, ovat aivan samalla tavalla "poliittista" kuin se, mitä parlamenteissa tapahtuu (Buckingham 2000, 204). Myös Buckingham (2000) varoittaa henkilökohtaisen politiikan ja mikropolitiikan sekoittumisesta toisiinsa. Henkilökohtainen politiikka voidaan nähdä mikropolitiikkana, mikäli se yhdistyy toisten ryhmien kokemuksiin esimerkiksi silloin, kun omat huolenaiheet risteytyvät muiden ryhmien samankaltaisten huolenaiheiden kanssa.

Tässä artikkelissa tarkastelemme lasten jokapäiväisen elämän neuvottelutilanteita esikouluissa ja alakouluissa Unkarissa ja kolmessa entisessä neuvostotasavallassa (Latviassa, Venäjällä ja Ukrainassa). Keskitymme koulupukuihin ja erityisesti tyttöjen hiuksiin kiinnitettyihin rusetteihin, joita kutsutaan venäjäksi nimellä bantik, latviaksi bante ja unkariksi masni. Siitä huolimatta, että olemme kasvaneet eri ympäristöissä maantieteellisesti ja ajallisesti - Zsuzsa Unkarissa, Iveta Latviassa, Nelli Venäjän Karjalassa ja Elena Ukrainassa - muistomme bantikeista resonoivat keskenään. Käytämme muistojamme sen purkamiseen, milloin ja miten rusettien sitominen ja päässä pitäminen (tai pitämättä jättäminen) - koulutytöksi tulemisen osana ja rituaalina - yhdistyi arkipolitiikkaan. Käytämme termiä "koulutyttö" laajasti käsittäen lapset laitoksissa, päiväkodeissa sekä esi- ja alakouluissa. Tarkoituksena on näyttää, miten nämä banaalit esineet - bantikit - sekä niihin liittyvät diskurssit ja käytännöt, tarjosivat 
poliittisen subjektiuden kehitysmahdollisuuksia. Rusetteihin keskittyminen mahdollistaa lisäksi niiden moninaisten tapojen paljastamisen, joilla tavanomainen esine ja tapa voivat tulla eri tavoin poliittisiksi erilaisissa geopoliittisissa ja henkilökohtaisissa ympäristöissä. Seuraavassa esittelemme ensiksi historiallisen taustan, jonka puitteissa analyysi toteutetaan, minkä jälkeen avaamme kollektiivisen biografian menetelmää, jonka avulla tutkimme niitä moninaisia tapoja, joilla lapsina osallistuimme arkielämän poliittisiin toimintoihin.

\section{Muistitarinoita lapsuudesta: Konteksti ja menetelmällinen lähestymistapa}

Arkielämä eri sosialistisissa yhteiskunnissa eri aikoina oli kaukana yhtenäisestä, ja meidänkin kokemuksemme kouluarkeen osallistumisesta ovat moninaisia. Valtiollisen sosialismin ensimmäinen vaihe Unkarissa (vuodesta 1948 1970-luvulle) johti demografiseen muutokseen, jonka seurauksena kaikki työikäiset naiset kävivät kokopäiväisessä palkkatyössä, ja naisten osuus lähes kaikilla koulutusjärjestelmän tasoilla saavutti miesten osuuden (Corrin 1993). Toisessa, reformistisen sosialismin vaiheessa (1970-luvulta vuoteen 1989) valtio vetäytyi osittain talouden piiristä (Lampland 1996). Tällä niin kutsutulla "varjotaloudella" sekä taloudellisten ja yhteiskunnallisten käytänteiden moninaistumisella esimerkiksi kauppatavaraistumisen muodossa (Lampland 1996) oli vaikutuksensa myös koulutukseen. Opetusohjelmista tehtiin yhä joustavampia, ideologisia käytäntöjä löyhennettiin, ja opettajien autonomia lisääntyi (Millei \& Imre 2010).

1970-luvulla ja 1980-luvun alussa koulutusinstituutiot Latviassa, Ukrainassa ja Venäjän Karjalassa olivat suurelta osin neuvostoliittolaisten standardisaatiokäytäntöjen ("venäläistämisen" tai "neuvostoliittolaistamisen") alaisia, mikä näkyi tiukan määriteltyinä opetussuunnitelmina, arkkitehtuurina ja koulupukuina. Neuvostoaikana Karjala kuului itsehallinnollisena alueena Venäjän sosialistiseen federatiiviseen neuvostotasavaltaan (SFNT), kun taas Latvia ja Ukraina muodostivat kaksi neljästätoista muusta neuvostotasavallasta. 1980-luvun keski- ja loppuvaiheilla kouluissa nähtiin perusteellisia muutoksia johtuen Gorbatšovin alulle laittamista perestroikasta sekä glasnostista. Neuvostoajan Latviassa nämä uudistukset osuivat suunnilleen samaan aikaan niin kutsutun "kansallisen heräämisen" (latv. atmoda) kanssa. Eri puolilla Neuvostoliittoa tämä aikakausi herätti uudelleen kansallisidentiteetit sekä vähemmistökielet ja -kulttuurit, mikä lopulta johti Latvian ja Ukrainan itsenäistymiseen vuonna 1991. Näiden muutosten kanssa samaan aikaan neuvostokoulujärjestelmän pohjimmaisia oletuksia alettiin asettaa yhä enemmän kyseenalaiseksi, erityisesti liittyen koulujärjestelmän ideologiseen luonteeseen sekä lapsikeskeisyyden ja kriittisen ajattelun puutteeseen (ks. Webber 2000; myös Janmaat \& Piattoeva 2007). Tänä aikana kouluja uudistettiin urakalla, mikä tarkoitti, että aiemmin täytäntöön pantuja standardeja löyhennettiin ja että opetussuunnitelmaa ja koulukulttuuria kehitettiin. Lopulta itsenäistyneet entisen Neuvostoliiton maat (mukaan lukien Venäjä, Latvia ja Ukraina) sekä Unkari pääsivät osallisiksi länsimaiseen (eurooppalaiseen) demokratiaan ja markkinatalouteen.

Tässä artikkelissa tarkastelemme omia henkilökohtaisia lapsuusmuistojamme kollektiivisen biografian kautta ${ }^{1}$. Kollektiivisessa biografiassa tuotetaan muistitarinoita, joita tulkitaan osallistujien intersubjektiivisten tilojen ja osallistujien nykyisyyksien ja menneisyyksien keskinäisten suhteiden näkökulmista. Täten emme voi väittää olevamme omien elettyjen kokemustemme neutraaleja tarkastelijoita. Me itse tutkijoina tutkimme omia muistojamme ja tutkimuksemme subjekti ja objekti ovat lomittuneita (Davies \& Gannon 2006; 2012). Lisäksi kaikki me neljä elämme ja työskentelemme ympäristöissä, joissa vallitsee modernit 
angloamerikkalaiset käsitykset minuudesta. Muistitarinoiden uudelleenmuistamiseen ovat vääjäämättä vaikuttaneet elämänkokemukset ja tietyt akateemisen koulutuksen kautta kehittyneet tieteelliset maailmankatsomukset.

Kollektiiviseen biografiaan ryhtymisen kautta pyrimme "tietämään eri tavalla, oman muistetun menneisyyden ja muiden menneisyyksien kautta" (Davies 2000, 187 siteerattu teoksessa Davies \& Gannon 2006, 33). Emme väitä, että tuottamamme tarinat heijastavat objektiivisia totuuksia. Näistä tarinoista kumpuavan "totuuden" ei ole tarkoitus validoida omien kokemuksiemme totuudenmukaisuutta vaan "tuottaa tietoa tavoista, joilla tietyissä hetkissä lihallistuu diskursiivisesti se, miten yksilöistä tehdään yhteiskunnan jäseniä” (Davies \& Gannon 2006, 4). Tieto nousee esiin muistojen välisissä tiloissa, joissa jokin yllättävä häiritsee tavanomaista ajattelutapaa ja esittää kysymyksiä, jotka laittavat uudelleentarkastelemaan itsestäänselvyyksinä pidettynä näkemyksiä jokapäiväisestä elämästä (Davies \& Gannon 2006). Hylkäämme käsityksen identiteetistä joukkona ominaispiirteitä tai ihmisen pohjimmaisena substanssina. Seuraamalla poststrukturaalisia lähestymistapoja ymmärrämme identiteetin ei sen ilmauksena, mitä ihminen on, vaan pikemmin jonain, mitä ihminen tekee, eli analyysin näkökulmasta jokapäiväisen elämän neuvottelun akteina. Täten kollektiivisen biografian kautta hylkäämme ajatuksen ihmisen pysyvästä identiteetistä ja lineaarisesta kehityksestä, myös politiikan osalta (Gonick \& Gannon 2014, 2), ja yhdistämme voimamme vastustaaksemme käsitystä "sosialistisesta minästä", jota me lapsina muovasimme, asutimme ja esitimme (Chatterjee \& Petrone 2008, 985).

Osallistuimme useisiin sekä verkossa että paikan päällä toteutettuihin kollektiivisen biografian työpajoihin (Davies \& Gannon 2006; 2012). Jalostimme lähtötarinoita toistuvien keskusteluiden, joiden aikana kysyimme toisiltamme selvennyksiä, sekä muistojemme affektiivisiin ja sensorisiin puoliin tutustumisen kautta. Yhdistyessämme muistojemme kautta autoimme toisiamme myös välttämään kliseitä ja nostalgisuutta. Muistitarinoiden jakaminen helpotti dialogia ja uusien muistitarinoiden syntymistä.

Analysoimme muistitarinoitamme diskursiivisina tuotoksina poststrukturaalisen diskurssianalyysin kautta ottaen huomioon toimijaverkkoteoriasta lainatut keskeiset toimijat (Latour 2005). Toimijaverkkoteoria auttaa harjoittamaan tutkijan havaitsemiskykyä ja tarkkanäköisyyttä, aisteja ja aistimisherkkyyttä (Mol 2010, 261-262). Osana tyttöjen koulupukua hiusrusetti objektina voidaan ymmärtää välikappaleeksi, jolla on kyky muuttaa, soveltaa, vääristää ja muokata niitä merkityksiä, joita sen on tarkoitus kantaa (Latour 2007 [2005], 39). Rusetin merkitysten ymmärtäminen tällä tavoin tarjoaa Molin mukaan mahdollisuuden nähdä, kuulla, tuntea ja näin analysoida asioiden sosiaalisia puolia - ja täten myös mahdollisuuden välittää niistä pikemmin kuin laiminlyödä niitä (Mol 2010, 255). Toimijat - sekä inhimilliset että ei-inhimilliset - muodostavat muiden toimijoiden kanssa verkostoja, joiden yhteistoiminnan kautta merkitykset muodostuvat. Analyysissamme pyrimme vastaamaan seuraaviin kysymyksiin: Miten neuvottelimme koululaisina jokapäiväisiä elämiämme suhteessa rusettien pitämiseen tai pitämättä jättämiseen; miten nämä toimet voisi ymmärtää poliittisina? Miten ymmärsimme rusetit ja saatavilla olevat diskurssit (ideologiset, arkiset tai muut)? Diskursiivisen ja aineellisen sotkeutumisen kautta muistitarinat avaavat keinoja makrososiaalisten prosessien ymmärrysten ja analyysien luontiin. 


\section{Koulupukujen ja rusettien "P"olitiikka ja "p"olitiikka}

Vaikka rusetti ilmentyi muistoissamme eri tavoin, se oli osa meidän kaikkien jokapäiväistä elämää. Tytöt joko pitivät rusettia päässä tai eivät, mutta silloin, kun niitä ei pidetty, niiden poissaolon tunsi, joten rusetit määrittivät kokemuksiamme:

Esikoulussa hänen odotettiin pitävän hiuksissa rusettia. Hänellä ei koskaan ollut pitkiä hiuksia, joten hän piti päässään isoja, pulleita rusetteja vain harvoin. Erityistapauksissa kaikkien tyttöjen odotettiin pitävän päässään valkoista rusettia, ja hän muistaa hämärästi kaivanneensa - vaikka vain hetken - että hänellä olisi samanlainen rusetti kuin muilla tytöillä. $^{2}$

Rusetin muistaminen ei ole helppoa. Ensimmäinen mieleen tuleva ajatus koskee koulukuvia: ryhmäkuva koulupuvussa, suuri rusetti poninhännälle laitetuissa hiuksissa, tai toinen kuva ensimmäisen luokan ensimmäisestä koulupäivästä. Hän on pukeutunut hassuun punaiseen karvatakkiin, hänen hiuksensa on letitetty ja letteihin kiinnitetty kaksi suurta rusettia. Vielä on yksi kuva, joka on myös otettu ensimmäisenä koulupäivänä, mutta sen on ottanut ammattikuvaaja (ks. Kuva 1). Tässä kuvassa hän istuu karttapallon vieressä ruskaisia lehtiä pulpetillaan ja aapinen käsissään. Letit olivat hänen tavanomainen hiustyylinsä, sillä muunlaisiin hänen äidillään ei ollut aikaa kiireisenä aamuna ennen töihin lähtemistä. Tavallisina päivinä letit pysyivät yhdessä yksinkertaisella läpinäkyvällä hiuslenkillä, mutta erityistapauksissa hiuslenkin sijaan hiuksiin laitettiin valkoinen rusetti. Hän ei koskaan pitänyt mustia tai ruskeita rusetteja, jotka oli tarkoitettu tavallisia koulupäiviä varten. Juhliin ja koulukuviin tarkoitettuja valkoisia rusetteja hän kuitenkin piti.

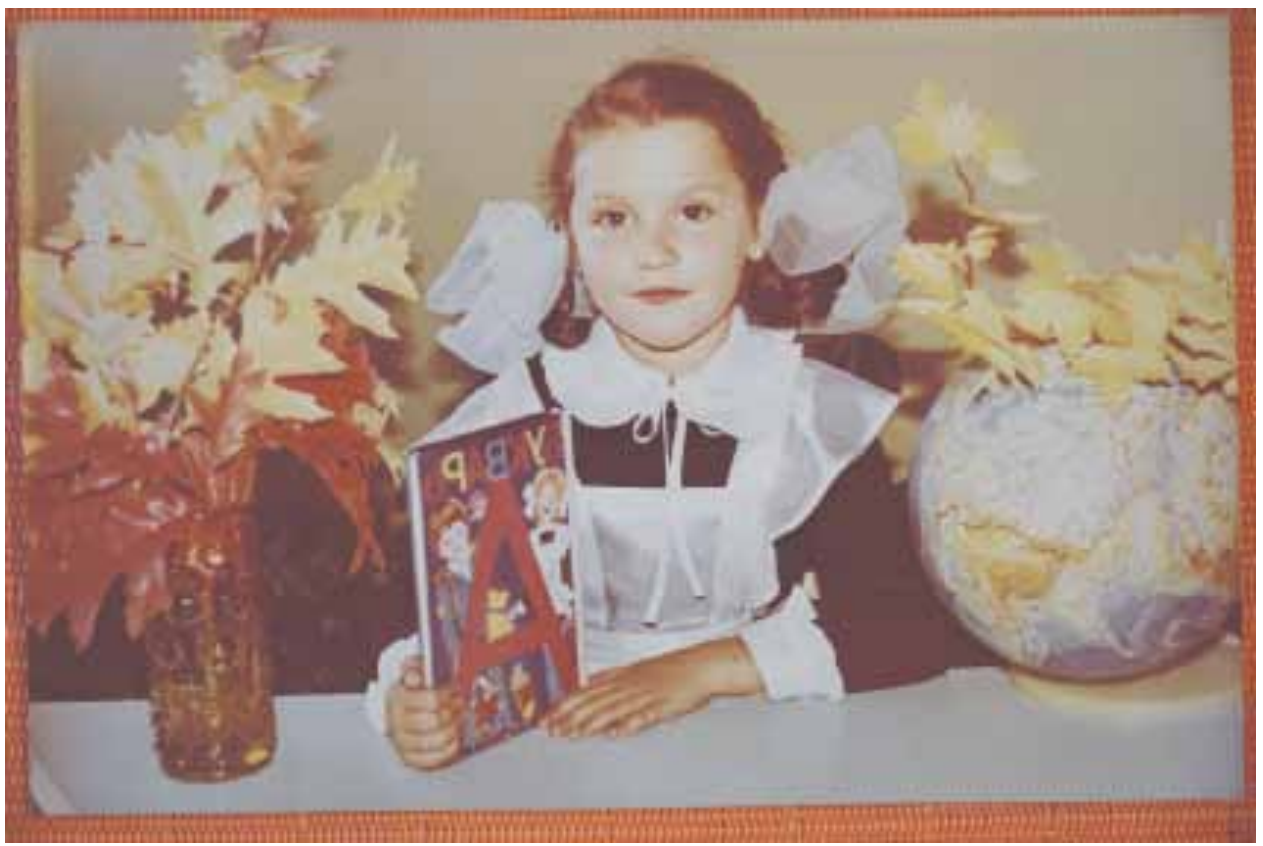

Kuva 1. Tyttö yllään koulupukuun kuuluva valkoinen esiliina ja valkoiset rusetit. Lähde: Nelli Piattoevan perheen arkisto. 
Bantikit ilmestyivät viralliseksi osaksi neuvostoaikaisia koulupukuja 1940-luvun lopulla, mikä heijastaa Neuvostoliiton koulutusviranomaisten pyrkimystä kannustaa käyttämään sukupuolitettua kouluasua (Kelly 2007, 379). Alkujaan bantikit olivat pieniä, vaatimattomia hiusnauhoja - valkoisia nauhoja pidettiin erityisinä päivinä ja tummia (yleensä ruskeita tai mustia) arkena. Neuvostoliiton talouden kasvettua toisen maailmansodan jälkeen kasvoivat kuitenkin myös bantikit. Tyttöjen hiuksiin huolellisesti solmitut pienet silkkinauhat muuttuivat äkkiä valtaviksi pulleiksi synteettisestä kankaasta tehdyiksi ruseteiksi, joita pidettiin pään päällä (ks. Kuva 2). Neuvostotasavalloissa tavallisista (joskin vähemmissä määrin Itä-ja Keski-Euroopan sosialistisissa maissa) ruseteista tuli idealisoidun neuvostolapsuuden symboli, johon heijastuivat kansallinen kukoistus, kehitys ja onnellisuus. Kun 1980-luvun alussa Amerikan nuori hyväntahdon lähettiläs, kymmenvuotias Samantha Smith, matkusti Neuvostoliittoon Juri Andropovin kutsusta, neuvostomedia käytti bantikeja erottamaan neuvostolapsen amerikkalaisesta. Eräs neuvostoliittolainen lehtitoimittaja kirjoitti Samantha Smithin matkasta:

\begin{abstract}
Samantha ihastui isoihin, valkoisiin rusetteihin, jollaisia hän ei ollut Yhdysvalloissa koskaan pitänyt päässään. Päiväkausia neuvostoliittolaiset pioneeritytöt toden teolla kilpailivat ja jonottivat saadakseen mahdollisuuden sitoa Samanthan rusettia. Kaikille se ei ollut mahdollista. [---] (Novyje Izvestija 2013.)
\end{abstract}

Bantikit olivat kaikkialla: julisteiden, aikakauslehtien kuvien ja maalausten mallitytöillä oli aina bantik päässä (Kelly 2006, 379). Ne olivat läsnä myös lasten kirjoissa, runoissa, elokuvissa ja jopa koulurakennusten sisäseinien muraaleissa (ks. Kuva 2 esimerkkinä kirjan kannesta, jossa tytöllä on päässään rusetti). Neuvostoliiton rajojen ulkopuolella, sellaisissa maissa kuin Unkari, rusettien suosio ei ollut yhtä ilmeinen. Niitä käytettiin lähinnä juhlatilaisuuksissa, kommunistisina juhlapäivinä sekä koulun tilaisuuksissa, kuten todistusten jaossa (Géczy 2010). Koulupuvuissa rusetteja käyttivät "pienet rummunsoittajat" (unk. kis dobos, luokat 1-4) sekä "pioneerit" (unk. úttörö, viidennestä luokasta eteenpäin) ja niitä käytettiin yleensä pitkissä hiuksissa. Rusetit solmittiin valkoisista nauhoista, ja niiden käyttö pohjautui sosialistiseen ideologiaan (Géczy 2010). Géczy (2010) on tutkinut lasten kuvia Unkarin sosialistiselta ajalta ja huomannut, että useimmissa kuvissa 1970-luvun Unkarista koulutytöillä oli lyhyet hiukset, kuten alla olevassa muistitarinassa, eikä lainkaan rusettia. Rusettien katoaminen unkarilaisista koulupuvuista tapahtui samaan aikaan kuin vaatetuksen muuttuminen yleisemminkin yksinkertaisemmaksi mukautuakseen muuttuviin käyttäytymismalleihin ja muutos kohti liberalisaatiota monilla elämän osa-alueilla.

Tyttöjen hiuksiin kiinnitettävät rusetit olivat osa koulupukua useimmissa neuvostoympäristöissä ja täten poliittisen sosialisaation mekanismi. Vaikka koulupuvut edistivät tasaarvoa, ne auttoivat myös normalisoimaan, muokkaamaan ja rankaisemaan lasten kehoja ja käyttäytymistä tehden lapsista sopivia koululaitoksen tarpeisiin (Meadmore \& Symes 1997; Kamler 1994). Pitämällä yllään koulupukua (mukaan lukien rusettia), lapset asemoituivat järjestelmän normistandardin määrittämään "oppilaan" subjektiasemaan (Kamler 1994). Rusetin sitomisen rituaali tai rusetin pitämisen mahdollisuuden menettäminen piti sisällään tuskaa ja vahvoja tunteita:

Hänellä oli lyhyet hiukset vain, kun hän oli hyvin pieni. Suunnilleen neljän ikäisenä hänen hiuksensa alkoivat kasvaa pidemmiksi. Aluksi, kun perheen piti matkustaa päiväkotiin 
junalla, äiti harjasi hänen hiuksensa ja sitoi bantikin junassa. Tyttö huusi kuin pistetty sika, sillä häntä sattui niin kovasti. Muut junamatkustajat puuttuivat tilanteeseen useita kertoja, milloin neuvoen äitiä pitämään tytön hiuksista kiinni eri tavalla niitä sitoessa, milloin ripittäen tätä huonosti käyttäytyvästä lapsesta, joka ei siedä kipua hiljaa. Kipu oli niin kova, että myöhemmin koulussa tyttö opetteli harjaamaan omat hiuksensa, ja sen sijaan, että hän olisi sitonut bantikilla poninhännän ja kiinnittänyt rusetin pään päälle, hän letitti hiukset saparoille. Se oli paljon helpompaa, ja bantik sai vain roikkua takana.

Hänen kokopäivätöissä käyvä äitinsä, joka oli korkeakoulutettu asiantuntija Unkarissa, laittoi aina hänen hiuksensa saparoiksi ylös päälaelle rusetille sidotuilla valkoisilla nauhoilla, jotka oli solmittu niin tiukalle, että ne tukistivat. Hiukset laitettiin nopeasti kiireisinä aamuina kaikkien valmistautuessa töihin tai kouluun. Tytölle tuli ihottuma jatkuvan tukistamisen vuoksi, ja terveydenhoitaja neuvoi äitiä joko leikkaamaan hiukset lyhyiksi tai antaa niiden olla auki muutaman päivän, jotta iho ehtisi parantua. Äiti ei pitänyt toisesta vaihtoehdosta. Tyttö aneli koko iltapäivän, ettei hänen hiuksiaan leikattaisi. He saapuivat äidin kampaajalle, ja odottaessa vuoroaan tyttö selasi kaikkia tyylikkäitä lyhyitä hiustyylejä lehdissä ja katseli salongin lyhythiuksisia naisia. Hän olisi silti halunnut pitää pitkät hiukset ja rusetilla sidotut saparot, jotta hän näyttäisi samalta kuin kaikki muutkin päiväkodin tytöt.

Samalla, kun hallintojärjestelmät tuottavat "hyviä" kansalaisia, jotka esimerkiksi haluavat pitää yllään rusettia ja näyttää samalta kuin muut, ne tuottavat diskursiiviseen järjestelmään myös "kapinallisia", vaikenemisia tai pieniä sisäisiä syrjäyttämisiä ja mutaatioita (Yurchak 2005), joihin lukeutuivat muun muassa yritykset kehittää vaihtoehtoisia, vähemmän tuskallisia mutta myös vähemmän virallisesti pakotettuihin normeihin istuvia tapoja rusetin käyttämiselle. Kuten Foucault $(1977,194)$ ehdottaa, kurillinen voimankäyttö ei ole vain negatiivista tai tukahduttavaa, se on myös tuottavaa, sillä se tuottaa tiettyä "todellisuutta"; se tuottaa objektien valtakuntaa ja totuuden rituaaleja. Lapset, suhteessa koulupukuihin yleisesti mutta rusetteihin erityisesti, toimivat silloin joko normalisoivien diskurssien, jotka tarjoavat keinoja olla "hyviä koulutyttöjä" tai jotain muuta, mukaisesti tai niitä vastaan. Koulutytöt voivat joko alistua näille normalisoiville diskursseille, vastustaa niitä tai toimia niiden puitteissa mutta sellaisilla tavoilla, jotka muokkaavat diskursiivista kehikkoa.

Kaipuu, tuska, turhautuminen ja häpeä säestivät kokemuksia rusetin päähän laittamisesta ja päässä pitämisestä. Ahmed (2015) pitää tunteita ja niiden avulla "tien tunnustelua" eräänlaisena maailman luomisena ja kulttuurin politiikkana. Rusetin kulttuurisen politiikan subjekteina toimimisen kautta, tuskan ja kaipuun tunteista lähtien, kehomme ja maailmamme materialisoituivat linjaan ideologian kanssa, jonka pakottamana rusettia pidettiin. Poliittiseksi tulemisessa tunteilla oli merkittävä rooli, mutta kuten kaikissa hallintojärjestelmissä, meillä oli mahdollisuus toimia "rusetilla puettuina subjekteina" myös toisilla tavoilla: uudelleentulkita rusetti, joko pitää sitä päässä tai olla pitämättä, tai jopa pitää lyhyitä hiuksia.

\section{"Mitä sinulla olisi ilman rusettia? Pelkkä pää!" - Rusetit ja ulkonäkö}

Dusselin $(2005,180)$ mukaan ulkomuotoon keskittymisellä on pitkä historia, ja sillä merkitään eroja, identifioidaan kuulumisen tiloja ja määritetään koulujen sisä- ja ulkorajoja. Rusetin sitomista ohjasi tietty tieto siitä, miltä sen kuuluisi näyttää, mikä loi "ulkonäköjärjestelmän", 
jonka alaisina yksilöt toimivat vastavuoroisesti tiettyihin tietoihin ja niihin liittyviin käytäntöihin nähden (Foucault 1994, 315). Ulkonäkö on Dusselin $(2005,185)$ mukaan myös sidottu siveellisyyteen, koska vaatteet informoivat muita henkilön moraalisesta tilasta, hänen hienotunteisuudestaan ja koulutuksestaan, ja siksi ulkonäön täytyy olla läheisen tarkkailun alla. Rusetin päässä pitämisen aktin kautta omaksuimme siistin ja järjestyksenmukaisen ulkonäön sekä moraalisen subjektiaseman hyvänä ja kunnollisena sosialistityttönä:

\begin{abstract}
Rusetit olivat osa kouluasua - samoin kuin esiliinat, kaulukset ja mansetit, jotka ommeltiin mekkoon kiinni - mutta rusetteja ei välttämättä käytetty muissa sosiaalisissa tilanteissa. Ystävien kanssa leikkiminen koulun jälkeen ei vaatinut rusettia - eivät myöskään perhejuhlat. Mutta perhejuhlissakin tai koulun juhlissa hiusten, erityisesti yli olkamittaisten, piti olla kiinnitettynä rusetilla tai pinneillä tai esimerkiksi saparoille laitettuna - hiusten auki pitämiseen täytyi kysyä vanhempien lupa. Tytön isoäiti kysyikin kerran: "Mitä sinulla olisi ilman rusettia? Pelkkä pää!”
\end{abstract}

Jos pidimme päässä tummaa rusettia, joka sopi yhteen arkipäiviksi tarkoitettuun koulupukuun kuuluvien tumman esiliinan ja sukkahousujen kanssa, vaatteiden likaantuminen oppituntien, välituntien tai ruokailun aikana oli sallittua, sillä lika ei näkyisi niin selvästi tummassa koulupuvussa. Tummassa asussa meillä oli siis lupa olla enemmän lapsekkaita ja erehtyväisiä, sillä meidän ei tarvinnut esittää täydellisen sosialistisen oppilaan roolia. Nämä värierot kouluasun tietyissä osissa - esiliinassa, ruseteissa ja sukkahousuissa - olivat hyvin informatiivisia. Niissä havainnollistuivat käyttäytymissäännöt, jotka kytkeytyivät eri fyysisiin ja ajallisiin tiloihin väriin tai vaatekappaleeseen tiivistetyn pukukoodin kautta.

Tunnistimme nämä ulkonäköerot ja alistuimme odotetuille normeille moninaisissa sosiaalisissa tilanteissa. Näin meistä tuli osallisia virallisten representaatioiden uudelleentuottamiseen. Rusetti oli koriste, joka kantoi symbolisia merkityksiä, joita me opimme suorittamaan käytännön tilanteissa. Yurchakin $(1997,168)$ mukaan se, uskoiko tietoisesti virallisesti julistettuihin tavoitteisiin, ei ollut yhtä tärkeää kuin vääjäämättömän rutiininomaisiksi nähtyihin virallisiin käytäntöihin osallistuminen. Yurchak käyttää tästä termiä "teeskennelty tietämättömyys" (engl. pretense misrecognition). Käyttämällä rusettia ja muita koulupuvun osia eri väreissä opimme navigoimaan sosiaalisissa tilanteissa, joissa sallittiin enemmän tai vähemmän vapautta ja joustoa. Tarvittaessa, yhdessä huoltajien ja opettajien kanssa, asemoimme itsemme linjaan sen kanssa, miltä lasten tulisi näyttää ja miten heidän tulisi toimia, vaikka emme uskoneet tai tunnistaneet taustalla olevaa virallista ideologiaa tai identifioituneet sosialisteiksi:

Virallisia koulukuvia varten tyttöjen piti pitää päällä kolmea valkoista asustetta: valkoista rusettia, valkoista esiliinaa ja valkoisia sukkahousuja. Jos jokin näistä asusteista puuttui, tällainen tyttö laitettiin seisomaan takariviin tai joku toiselta luokalta lainasi tälle puuttuvat asusteet. Opettajat eivät kiivastuneet, kun näin tapahtui, vaan he yrittivät rauhallisesti korjata tilanteen.

Eräänä päivänä esikoulussa oli koulukuvauspäivä. Tytön vanhemmat eivät olleet paikalla, kun kuvat otettiin, sillä he olivat töissä. Lastenhoitaja avusti opettajaa saamaan lapset valmiiksi kuvausta varten, ja katsoessaan tyttöä hän huudahti myötätuntoisesti: ”Tyttörukka! Eihän sinulla ole edes rusettia! Minä laitan sinut yhtä kauniiksi kuin muut 
tytöt. Minä teen sinulle rusetin!”. Hän otti yltään suuren huivinsa ja taianomaisesti teki siitä ison purppuranvärisen rusetin. Tyttö kihelmöi onnesta, mutta häntä myös jännitti iso pullea rusetti, joka yhtäkkiä laskettiin hänen päänsä päälle. Hän ei oikein tiennyt mitä ajatella mutta meni tilanteen mukana.

Neuvostokoulumuistoissamme koulutytöt pukeutuivat valkoisiin esiliinoihin ja rusetteihin silloin, kun piti osallistua virallisiin rituaaleihin, jotka ikään kuin simuloivat pinnallista tukea järjestelmälle. Tällaisia tilanteita olivat esimerkiksi kuvauspäivät kouluissa silloin, kun koulu alkoi (ks. Kuva 1) tai kun koulu sai tärkeitä vierailijoita, joille opettajat pitivät esittelytunteja (ven. pokazatelnyje uroki). Esiripun takana meillä oli kuitenkin omat tapamme uskoa näihin symboleihin, merkkeihin ja representaatioihin. Prototyyppiset kouluasut peilasivat esimerkillistä käyttäytymistä - kun virheitä ei voinut tehdä, tahrattomat valkoiset esiliinat ja sukkahousut pakottivat meidät käyttäytymään kunnolla ja varomaan joka askelta. Opettaja ja valokuvaaja toimivat täydellisen ulkoasun vahtijoina - he muokkasivat ja tarpeen vaatiessa jopa piilottivat sääntöjen rikkojia siirtämällä heidät täydellisesti pukeutuneiden luokkatovereidensa taakse tai tekemällä heille rusetin. Me kaikki kuitenkin ymmärsimme, etteivät nämä odotukset olleet vaatimuksia jokapäiväiselle elämällemme.

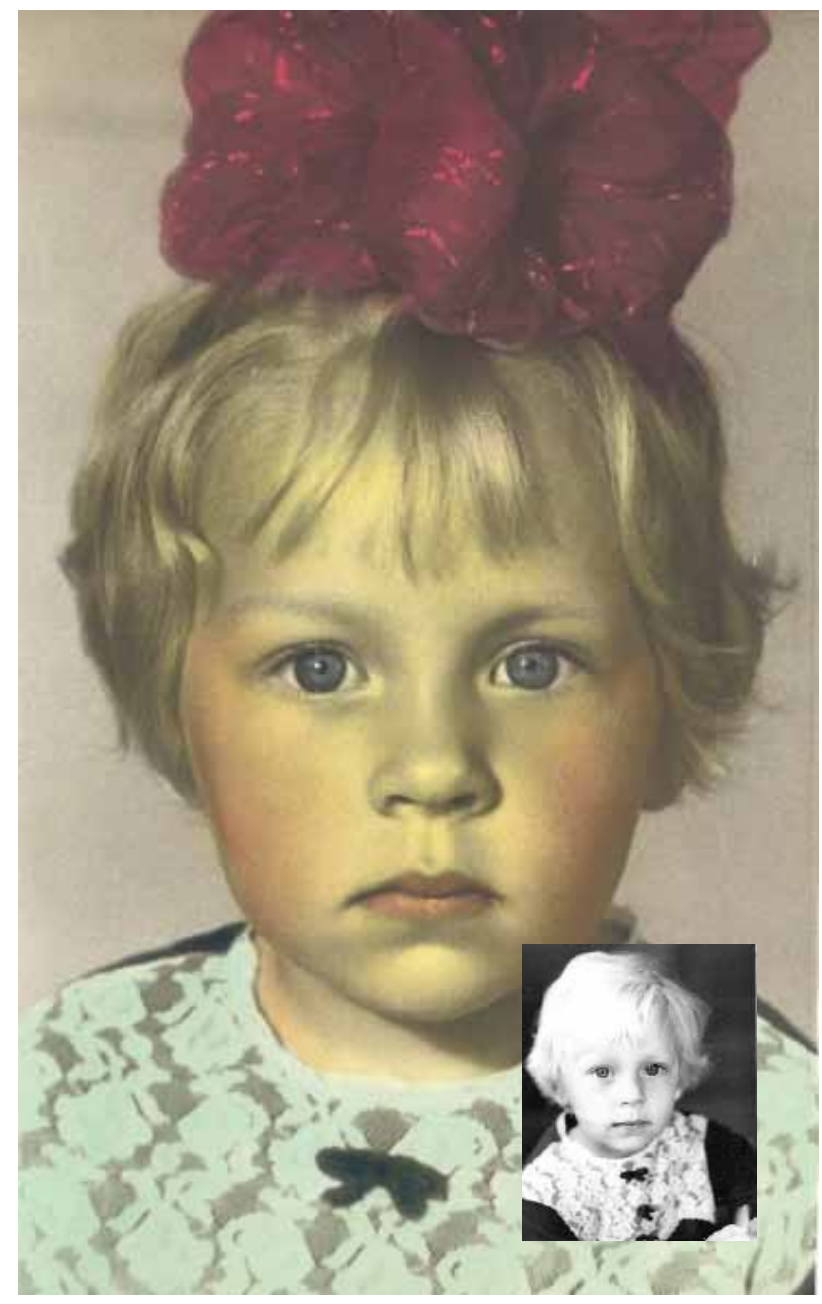

Kuvat 2 \& 3. Kaksi kertaa samana koulukuvauspäivänä kuvattu tyttö - rusetin kanssa ja ilman. Lähde: Iveta Silovan perheen arkisto. 


\title{
Rusetit ja siirtymät tilojen välillä
}

Tähän asti olemme väittäneet, että rusetti asetti meidät tiettyihin koulun ulkoasun ja järjestyksenmukaisuuden muotoihin, normeihin ja käytäntöihin. Rusetin pukeminen oli rituaali, joka merkitsi siirtymiä erilaisten tilojen välillä antaen signaalin kantajalleen, että erilaiset käyttäytymissäännöt pätivät siitä hetkestä, kun rusetti puettiin. Oli kuin olisimme olleet teatterin näyttelijöitä, jotka valmistautuivat rooleihin pukemalla esiintymispuvun ja siihen kuuluvan naamarin. Tunsimme itsemme normaaleiksi subjekteiksi, jotka "näkivät kyllä totuuden naamarin takana, mutta eivät voineet muuta kuin teeskennellä, että naamari oli oikea naama" (Yurchak 1997, 180).

\begin{abstract}
Kun hän katsoo kouluajan ulkopuolella otettuja perhekuvia, hän näkee hymyilevän tytön, jolla on kaksi lettiä ja joka pitää yllään vaatteita, jotka perheenjäsen on tuonut toisesta sosialistisesta maasta, eikä tämä tyttö muistuta lainkaan koulussa otettujen kuvien tyttöä. Hän ei lainkaan muista hetkiä, joina äiti sitoi rusetin hiuksiin, tai tunteita tai aistimuksia, jotka liittyisivät rusetteihin. Kaikki mitä hän näkee edessään, on kuvia hänestä itsestään, jotka eivät kuitenkaan näytä häneltä. Hän muistaa tunteneensa olonsa epämukavaksi katsoessaan lapsena näitä kuvia - aivan kuin hän katsoisi jotakuta muuta kuin oikeaa omaa itseään.
\end{abstract}

Epätoden tuntu oli osa ikään kuin kaksinkertaista teeskentelyä, sillä sosialistinen valtio itsessään oli teeskentelyä, ja me itse teeskentelimme olevamme sosialistisia kansalaisia. Tarina pulleasta huivista solmitusta rusetista jatkuu: Sinä päivänä valokuvaaja otti tytöstä kaksi kuvaa - yhden siten kuin hänen vanhempansa odottivat (ks. Kuva 2) ja yhden siten kuin esikoulu suositteli (ks. Kuva 3). Kenties virallisesti koulukuvauspäivänä vain yksi kuva olisi vaadittu rusetin kanssa, mutta kaksi kuvaa otettiin. Kahden kuvan mahdollisuus, rusetin kanssa ja sitä ilman, näyttäytyy ohituksena diskursiivisessa järjestelmässä. Diskursiivisen järjestelmän ohituksen välitilassa voimme nähdä rusetin pukematta jättämisen lapsilähtöiseksi politiikaksi.

Kenties johtuen kiusallisuuden ja hämmentyneisyyden tunteista, jotka puskevat hänen päälleen aallon tavoin, kun hän näkee ensimmäisen esikoulussa otetun kuvansa, jossa hänellä on iso rusetti päällä, tyttö muistaa, ettei kuvien saapuessa kotiin tunnistanut kuvan kasvoista omaa "oikeaa" itseään. Epämukavan vieraantumisen tunteen kautta näiden rinnakkaisten tilojen yhteensopimattomuus todellistui hänelle, vaikkei se ollut vielä silloin hänelle täysin ymmärrettävää. Tähän tilanteeseen päälle laitettu ideologinen naamari sai tytön tuntemaan olonsa epämukavaksi. Vaikka tunne ei johtanut välittömiin toimiin, jotka olisivat eksplisiittisesti vastustaneet järjestelmän teeskenneltyä luonnetta ja siihen liittyviä käytäntöjä, kiusallinen tunne asetti nämä (enemmän tai vähemmän ideologiset) diskurssit ja tilat tarkkailun ja kyseenalaistuksen kohteiksi. Väitämmekin, että näiden jokapäiväisten diskurssien sekä niihin liittyvän tunteiden kulttuurisen politiikan tunnistaminen, tarkkailu sekä niiden kanssa, sisässä ja niitä vastaan toimiminen merkitsee tavanomaista lapsuuden politiikkaa sosialistisen vallan aikana.

Tarina rusetista jatkuu merkitsevällä poliittisella toimella vanhempien osalta sen jälkeen, kun he näkivät, että heidän tyttärestään oli otettu kaksi kuvaa:

Tyttö tajusi myöhemmin, että hänen vanhempansa eivät juuri välittäneet isoista pulleista ruseteista. "Rusetit ovat venäläisille lapsille", hänen Omansa (isoäitinsä) oli sanonut. Ja 
hän oli kielellisesti ja etnisesti latvialais-venäläisestä perheestä. Kun hänen vanhempansa saivat kuvat muutamaa viikkoa myöhemmin, he järkyttyivät. Tytön isä oli erityisen tyytymätön, ja hän uhkasi mennä esikoululle ja tehdä valituksen koulun johtajalle. Tyttö muistaa anelleensa isäänsä olemaan tekemättä sitä ja sanoneensa: "Ei siinä ole mitään väärää, isä... sehän on vain rusetti. Näytän samalta kuin muut tytöt nyt... Ole kiltti äläkä sano mitään koulun johtajalle!” Skandaalinomainen rusettiepisodi jätti syvälle hänen sisimpäänsä syyllisyyden ja hämmentyneisyyden tunteen... sekä kuvatodisteen siitä, miten ymmällään hän oli virallisessa valokuvassa iso pöyheä rusetti päänsä päällä.

Tässä tytön vanhemmille rusetti merkitsi kansallisen kuulumisen tunnetta, kun taas meille lapsille ulkoasu oli juuri sitä - pelkästään ulkoasua. Näin opimme myös samaistumaan niihin. Aivan kuten aikuiset teeskentelivät seuraavansa ideologiaa pintapuolisesti, olevansa läsnä fyysisesti mutta ei emotionaalisesti tai kognitiivisesti, mekin tiesimme sen riittävän, että näyttää siltä miltä oletetaan ilman, että ruumiillistuu läpikotaisin ideologian mukaiseksi. Tämä käytös ei merkinnyt aktiivista vastustusta tai kumouksellisuutta vaan aktiivista tietämättömyyttä tai kenties tilanteiden luovaa uudelleentulkintaa. Aivan kuin eräs isoäiti vastasi kysymykseen rusettien roolista - "Ne vain olivat." Pikkutarkan ulkonäköön keskittymisen kautta opimme, ehkä tiedostamattomasti, miten ovela (myöhäis)sosialistisen ajan todellisuus oli - asioiden piti "näyttää oikealta" ja se riitti. Puolueen viralliselle linjalle uskollisuuden sijaan opimme tulkitsemaan näitä representaatioita tehden niistä omiamme. Aiemmin mainittu Yurchakin (1997) "teeskennelty tietämättömyys" kuvaa hyvin tätä monimerkityksistä suhdetta järjestelmään. Tällaiset poliittiset aktit eivät huokuneet vallan pilkkaamista tai vastustamista vaan pikemmin "kiinnostuksen puutetta siihen" (Yurchak 1997, 162-163). Tällä tavoin poliittinen teeskentely ja tietämättömyys opittiin osana tavanomaista koulunkäyntiä. Siinä missä politiikka assosioidaan usein ryhmiin liittyvien agendojen kiinnostuksen olemassaoloksi, tässä "kiinnostuksen puute" ja epämukavuuden tunne, joka liittyi toistuviin erilaisissa tiloissa erilaisena koulutyttönä toimimisen käytäntöihin, antoi mahdollisuuksia lapsuuden politiikkaan tavanomaisessa arkielämässä.

\section{Lopuksi}

Sovelsimme arkipolitiikan käsitettä sosialististen yhteiskuntien lapsuuden ja koulunkäynnin jokapäiväisiin tiloihin. Muistitarinoidemme kautta tutkimme, miten lapset jokapäiväisessä elämässään ymmärtävät ja luovat poliittisia tiloja, jotka linkittyvät muiden ryhmien viralliseen politiikkaan tai arkipolitiikkaan. Foucault'laisesta näkökulmasta toiminta on aina jo valmiiksi käsikirjoittamaa, toisin sanoen operatiivisten diskurssien muodostamaa ja niiden sisällä tai kanssa tai niitä vastaan toimivaa. Rusetteja sitomalla, kiinnittämällä ja päässä pitämällä - tai pitämättä jättämällä - luimme ja toimimme joko operatiivisten diskurssien kanssa tai sisällä taikka niitä vastaan. Jotkut operatiivisista diskursseista olivat eksplisiittisen ideologisia ja jotkut banaaleja. Rusettiin liittyvän toimintamme ja ymmärryksemme kautta olemme tulkinneet virallisia representaatioita ja ideologioita omilla tavoillamme ja omilla ehdoillamme. Arkisten aktiemme kautta liityimme hiljaa muihin, jotka eivät olleet kiinnostuneita virallisesta ideologiasta, teeskentelivät tukevansa sitä ja/tai osallistuivat pieniin virallisia odotuksia vastustaviin akteihin. Opimme lukemaan tiloja ja diskursiivisia muodostelmia, jotka liittyivät kouluihin, koululuokkiin, kokoontumistiloihin, kampaamoihin tai koteihin ja jotka olivat latautuneita virallisella ideologialla tai saivat latauksensa ihmisten jokapäiväisestä 
osallistumisesta niihin. Näissä tiloissa "oppiminen on prosessi, jossa tutustutaan operatiivisiin sääntöihin ja tapoihin sekä saatavilla olevien diskurssien ja subjektiasemien tekstuureihin ja rajoihin, jossa löydetään paikka näiden sisältä tai niitä vastaan ja jossa tullaan subjektiksi ja ihmiseksi, uudelleen ja uudelleen prosessin aikana" (Davies et al. 2001, Petersen \& Millein 2015, 26, mukaan).

Samalla tavoin Alexei Yurchak (2005) selittää, että toimijuutta ei tulisi ymmärtää avoimena virallisen poliittisen järjestelmän vastustuksena vaan merkityksettömien ja usein näkymättömien toimintojen kautta. Näissä teoissa toteutetaan pienen pieniä sisäisiä syrjähyppyjä ja mutaatioita diskursiivisessa järjestelmässä, eikä niiden "tarvitse olla ristiriidassa järjestelmän poliittisten ja eettisten parametrien kanssa, ja, mikä tärkeintä, ne voivat jopa sallia järjestelmän mahdollisuuksien, lupausten, positiivisten ideaalien ja eettisten arvojen säilyttämisen samalla vältellen niitä negatiivisia ja sortavia rajoituksia, joiden sisässä ne ilmenevät" (Yurchak 2005, 28).

Yurchakin (2005) mukaan "epävirallinen" ei tarkoittanut pelkästään jotain, joka salli vallalla olevan poliittisen ideologian vastustamista, vaan se myös piti järjestelmää sellaisenaan yllä. Samaan tapaan julistetun ideologian vastaiset toimet ilmenivät ikään kuin ulospäin suuntautuvana virallisen politiikan vastustuksena, ja ne pitivät sisällään eri tavalla poliittisia toimia esimerkiksi huumorin tai teeskentelyn keinoin. Näiden monisyisten poliittisten kenttien puitteissa ymmärsimme itsemme lapsiksi tai koulutettaviksi subjekteiksi, ja vallalla olevat diskurssit sanelivat toimintaamme. Identiteetin muodostamisen ja muokkaamisen kautta pyrimme tulemaan tietynlaisiksi sosialistisiksi koulutytöiksi (Davies et al. 2001; Kofoed 2008). Erilaiset tilat mahdollistivat eri tavoin toistettavia toimia sekä toimimattomuuksia, tunteita, jotka saivat meidät tutustumaan operatiivisiin diskursseihin ja subjektiasemiin. $\mathrm{Ne}$ myös tuottivat tilaisuuksia poliittisesti toimimiseen liittymällä kollektiiviseen kamppailuun vallan saamiseksi omien välittömien olemassaolon ehtojen yli. Tällä tavoin rusetti antoi tilaisuuden toimia poliittisesti, loi siltoja politiikan ja lapsuuden jokapäiväisten tilojen välille sekä loi tiloja lasten "p"olitiikalle.

Muistitarinoidemme kautta pyrimme problematisoimaan vallitsevan käsityksen sosialistisesta ja jälkisosialistisesta koulujärjestelmästä yksiselitteisesti tukahduttavana ja monipuolistamaan ymmärrystämme politiikasta tuomalla esiin lasten politiikan. Täten näemme valtavasti potentiaalia (jälki)sosialismin käsitteessä ja maantieteellisessä alueessa johtuen monimutkaisesta poliittisesta taktikoinnista, johon osallistumista meiltä lapsina vaadittiin. Muistitarinamme eivät keskustele vain menneisyydestä, vaan niistä tulee pikemmin hedelmällistä maata meidän nykyaikaiselle politiikanymmärryksellemme, poliittiselle toimijuudelle sekä subjektin muotoutumiselle, jota täytyy tutkia tarkemmin. Lapsuusmuistomme ovat rikas resurssi ja ne monimutkaistavat ja monipuolistavat ymmärrystä siitä, mitä oli olla koululainen kylmän sodan aikana. 


\section{Viitteet}

1 Suomessa tätä menetelmää ovat käyttäneet ja kehittäneet mm. Palsaoja -kollektiivin jäsenet (ks. Palsaoja -kollektiivi 2018).

2 Kollektiivisessa biografiassa muistot työstetään yhteisöllisesti ja yhteisöllisiksi eikä niihin merkitä "tekijää". Sen vuoksi muistoissa ei myöskään käytetä minä-muotoa.

3 Englanninkielinen alkuperäisteksti Hair Bows and Uniforms: Entangled Politics in Children's Everyday Lives on ilmestynyt alunperin kirjassa Childhood and Schooling in (Post)Socialist Societies. Memories of Everyday Life. Eds. Iveta Silova, Nelli Piattoeva \& Zsuzsa Millei. Palgrave Macmillan, 2017, 145-162.

\section{Lähteet}

Ahmed, Sarah (2015), The Cultural Politics of Emotions. 2nd ed. New York \& London: Routledge.

Althusser, Louis (1971), Ideology and ideological state apparatuses. - Lenin and Philosophy and Other Essays. Ed. Louis Althusser. New York: Monthly Review Press. https://www.marxists.org/ reference/archive/althusser/1970/ideology.htm

Buckingham, David (2000), After the Death of Childhood: Growing Up in the Age of Electronic Media. Cambridge: Polity Press.

Chatterjee, Choi \& Petrone, Karen (2008), Models of Selfhood and Subjectivity. The Soviet Case in Historical Perspective. - Slavic Review 67:4, 967-986.

Connell, Bob (1987), Why the "Political Socialization" Paradigm Failed and What Should Replace It. - International Political Science Review 8:3, 215-223.

Corrin, Chris (1993), Magyar Women: Hungarian Women's Lives 1960s-1990s. London: St. Martin's.

Davies, Bronwyn \& Gannon, Susanne (2012), Collective biography and the entangled enlivening of being. - International Review of Qualitative Research 5:4, 357-376.

Davies, Bronwyn \& Gannon, Susanne (2006), Doing Collective Biography: Investigating the Production of Subjectivity. Maidenhead: Open University Press.

Davies, Bronwyn, Dormer, Suzy, Gannon, Sue, Laws, Cath, Rocco, Sharn, Taguchi, Hillevi Lenz \& McCann, Helen (2001), Becoming Schoolgirls: The Ambivalent Processes of Subjectification. Gender and Education 13:2, 167-182.

Dussel, Inés (2005), When Appearances Are Not Deceptive. A Comparative History of School Uniforms in Argentina and the United States. - Paedagogica Historica: International Journal of the History of Education 41:1-2, 179-195.

Foucault, Michel (1994), The ethics of the concern for the self as a practice of freedom (R. Hurley, Trans.). - Michel Foucault Ethics Subjectivity and Truth. Ed. Paul Rabinow. London: Allen Lane, The Penguin Press, 281-302.

Foucault, Michel (1977), Discipline and Punish: The Birth of the Prison. London: Penguin.

Géczi, János (2010), Sajtó, kép, neveléstörténet: Tanulmányok. Veszprém \& Budapest, Hungary: Iskolakultúra.

Gonick, Marnina \& Gannon, Susanne (2014), Becoming Girl: Collective Biography and the Production of Girlhood. Toronto, ON: Women's Press.

Janmaat, Jan Germen \& Piattoeva, Nelli (2007). Citizenship Education in Ukraine and Russia: Reconciling Nation-Building and Active Citizenship. - Comparative Education 43:4, 527-552.

Kallio, Kirsi Pauliina (2014), Rethinking Spatial Socialisation as a Dynamic and Relational Process of Political Becoming. - Global Studies of Childhood 4:3, 210-223.

Kallio, Kirsi Pauliina \& Häkli, Jouni (2011), Are There Politics in Childhood? - Space \& Polity 15:1, $21-34$. 
Kamler, Barbara (1994), Shaping Up Nicely: The formation of Schoolgirls and Schoolboys in the First Month of School: A Report to the Gender Equity and Curriculum Reform Project. Department of Employment, Education and Training. Canberra, ACT: Australian Government Publication Service.

Kelly, Catriona (2007), Children's World: Growing Up in Russia, 1890-1991. New Haven (Conn.): Yale University.

Kofoed, Jette (2008). Appropriate pupilness: Social categories intersecting in school. - Childhood $15: 3,415-430$.

Lampland, Martha (1996), The Object of Labor: Commodification in Socialist Hungary. Chicago, IL: University of Chicago Press.

Latour, Bruno (2007 [2005]), Reassembling the Social. An Introduction to Actor-Network-Theory. Oxford: Oxford University Press.

Mead, Michael. A. \& Silova, Iveta (2013), Literacies of (Post)Socialist Childhood: Alternative Readings of Socialist Upbringings and Neoliberal Regimes. -Globalization, Societies, Education $11: 2,194-222$.

Meadmore, Dephne \& Symes, Colin (1997), Keeping Up Appearances: Uniform Policy for School Diversity? - British Journal of Educational Studies 45:2, 174-186.

Millei, Zsuzsa (2011), Governing Through the Early Childhood Curriculum, "The Child", and "Community": Ideologies of Socialist Hungary and Neoliberal Australia. - European Education 43:1, 33-55.

Millei, Zsuzsa \& Imre, Robert (2010), Re-Thinking Transition Through Ideas of "Community" in Hungarian Kindergarten Curriculum. - Post-Socialism is Not Dead: (Re)reading the Global in Comparative Education. International Perspectives on Education and Society. Ed. Iveta Silova. Bingley, UK: Emerald, 125-154.

Millei, Zsuzsa \& Petersen, Eva Bendix (2015), Complicating "Student Behaviour": Exploring the Discursive Constitution of "Learner Subjectivities". - Emotional \& Behavioural Difficulties 20:1, 20-34.

Mol, Annemarie (2010), Actor-Network Theory: Sensitive Terms and Enduring Tensions. - Kolner Zeitschrift fur Soziologie und Sozialpsychologie 50, 253-269.

Novyje Izvestija (2013), Bantiki Dlja Samanty. https://newizv.ru/news/society/12-07-2013/185501bantiki-dlja-samanty

Palsaoja-kollektiivi (2018), Liike ja Hetki. Kollektiivisen Biografian Sommitelmia (Nyky)Akatemiassa. Jyväskylän yliopisto: Sophi.

Philo, Chris \& Smith, Fiona M. (2003), Guest Editorial: Political Geographies of Children and Young People. - Space and Polity 7:2, 99-115.

Silova, Iveta (2010), Rediscovering Post-Socialism in Comparative Education. - Post-Socialism is Not Dead: (Re)reading the Global in Comparative Education. International Perspectives on Education and Society. Ed. Iveta Silova. Bingley, UK: Emerald, 1-24.

Skelton, Tracey (2013), Young People, Children, Politics and Space: A Decade of Youthful Political Geography Scholarship 2003-13. - Space \& Polity 17:1, 123-136.

Skelton, Tracey (2010), Taking Young People as Political Actors Seriously: Opening the Borders of Political Geography. - Area 42:2, 145-151.

Taylor, Charles (1989), Sources of the Self: The Making of the Modern Identity. Cambridge, Mass.: Harvard University Press.

Webber, Stephen (2000), School, Reform and Society in the New Russia. Basingstoke: Macmillan.

Yurchak, Alexei (1997). The Cynical Reason of Late Socialism: Power, Pretense and the Anekdot. Public Culture 9:2, 161-188.

Yurchak, Alexei (2005). Everything Was Forever, Until It Was No More: The Last Soviet Generation. Princeton: Princeton University Press. 